\title{
Sewage Flow Conditions in a Hydroponic Lagoon in Terms of Quality of Treated Wastewater
}

\author{
K. Marek $\cdot$ K. Pawęska $\cdot$ A. Bawiec $\cdot$ J. Baran
}

Received: 24 February 2021 / Accepted: 13 June 2021 / Published online: 28 June 2021

(C) The Author(s) 2021

\begin{abstract}
The aim of this study was to analyse the impact of velocity in the hydroponic lagoon used as the 3rd stage of municipal wastewater treatment on washing out of the particles suspended in the sewage as well as settled on the bottom of the hydroponic ditch. In order to analyse the flow velocity in the lagoon, 12 cross-sections were determined at points where the speed and motion of particles can change. Wastewater samples were taken in the summer month from each of the 12 sampling points (the depth of $0.1 \mathrm{~m}$ ) and the basic physicochemical parameters of sewage were determined (BOD5, COD, TOC, TSS, turbidity). In selected cross-sections, a granulometric analysis of particles was made to determine the characteristics of suspended solids in the wastewater flow path. Based on the analysis, it was found that velocities in the lagoon during aeration can be
\end{abstract}

K. Marek · K. Pawęska · A. Bawiec $(\bowtie)$

Institute of Environmental Engineering, The Faculty

of Environmental Engineering and Geodesy, Wrocław

University of Environmental and Life Sciences,

Grunwaldzki Square 24, 50-363 Wrocław, Poland

e-mail: aleksandra.bawiec@upwr.edu.pl

K. Marek

e-mail: 109058@student.upwr.edu.pl

K. Pawęska

e-mail: katarzyna.paweska@upwr.edu.pl

J. Baran $(\bowtie)$

HaskoningDHV Polska Sp. z o.o, Sikorskiego Str. 2-8,

53-659 Wrocław, Poland

e-mail: jeremi.baran@ rhdhv.com ten times higher $\left(0.070 \mathrm{~m} \cdot \mathrm{s}^{-1}\right)$ than those assumed by designers $\left(0.006 \mathrm{~m} \cdot \mathrm{s}^{-1}\right)$. Such a large difference means that the sedimentation conditions assumed in the project cannot be met, which may result in an increase in the total suspended solids and organic matter concentrations at the outflow to the receiving water body. During the flow through the hydroponic ditch, the highest efficiency of pollutant removal was indicated for BOD5 - 88.7\% and TSS - 80\%, while the COD removal occurred with the lowest efficiency $-34.1 \%$. Improving flow conditions as designed in the hydroponic lagoon technological project may increase the efficiency of wastewater treatment at the third stage of treatment.

Keywords Municipal wastewater - Water velocity · Granulometric composition · Hydroponic lagoon · Organic matter

\section{Introduction}

Higher and higher standards for the quality of treated wastewater discharged to the receiver became a motivation to look for high-performance technological solutions. There are many dangerous substances in municipal sewage, which introduced into the environment without purification can disrupt the natural balance of receivers (Jin et al., 2017). One of the extremely important parameters related to the quality of sewage is the organic matter concentration, which 
can strongly affect the development of bacterial flora and lead to oxygen depletion (Atique \& An, 2020). The most important organic matter indicators in sewage are biochemical oxygen demand (BOD5), chemical oxygen demand (COD), total organic carbon (TOC) (Szabo \& Lepistö, 2020). The total suspended solids (TSS) concentration largely influence organic matter content in the water courses sediments which became a significant factor in water pollution (Zhu et al., 2017). Ensuring appropriate sewage flow rates through the wastewater treatment plant (WWTP) significantly influences the organic matter content in the sewage stream. In natural river ecosystems, the hydraulic conditions are one of the major factors that affect spreading and degradations of pollutants. Changes and fluctuations in water flow can alter habitat conditions and disturb the ecological balance resulting in changes in physical and chemical properties of water (Panda et al., 2015). Wastewater treatment technologies imitating natural conditions are gaining popularity around the world. The most popular semi-natural systems include constructed wetlands, sewage oxidation or stabilisation ponds, and hydroponic systems (Maiga et al., 2017). This type of solutions is used as the third or fourth stage of treatment not only of sewage but also as a purification system for contaminated water from aquaculture (Keeratiurai, 2013). The water flow velocity and aeration in flowing waters are the most beneficial conditions in terms of self-cleaning processes (Taseiko et al., 2016). Therefore, so-called "artificial rivers" are used in the wastewater treatment systems. One of the most popular solutions are hydroponic lagoons with macrophytes supporting the purification process (Gosh \& Desai, 2006). Plants floating on the surface of wastewater with the roots freely immersed in sewage can uptake nutrients directly from the solution and are perfect habitat to many desirable bacteria, protozoa, molluscs and invertebrates (Bawiec et al., 2020).

In the hydroponic lagoon, the wastewater movement is mainly caused by the appropriately modelled drop of the trough bottom as well as by the installation and operation of the aerators. Hydroponic lagoon systems provide oxygen necessary for the mineralization of organic matter. In the aeration conditions of the hydroponic lagoon, after 4 days, a reduction of BOD5 content by about $30 \%$ can be observed. In the case of a suspension after $12 \mathrm{~h}$ of sedimentation, $80 \%$ of the organic particles will be located in the sediment (Suryani, 2017). Sewage flow in aerated hydroponic lagoon systems should ensure sedimentation of organic matter remaining after previous purification processes without a marked increase in its level at the outflow. As shown by Huang et al. (2017), on one hand, the degradation rate of selected pollutants (including COD) in artificial river bed increases with the increase of water velocity, on the other hand, it disturbs sedimentation conditions. The use of aerators without the simultaneous control of the speed of sewage flow, rapid speed increases, the creation of a flow opposite to the assumed direction may lead to the lifting of the previously suspended particles. Resuspension of sediments and its discharge to the receiver may cause a decrease of oxygen concentration in water column affecting the whole ecosystem stability (Brodersen et al., 2017). In the systems with well-developed aquatic vegetation, the resuspension of fine particles may lead to particles adhesion to the surface of plants roots, stems and leaves and thus to their photosynthetic capacity reduction. The exchange of gas and nutrients between macrophytes and water can be disrupted (Wang et al., 2015). It is extremely important to control the flow conditions that translate into the expected effects of the suspended solids and organic matter removal in the hydroponic systems.

Analysing the movement of solid bodies in aerated lagoons, the rapid increase in velocities caused by aeration and its decreases caused by even arches of the hydroponic ditch can be noticed. Another observed regularity is the occurrence of local deposition of the particles set in motion by the increased point speed (Wu, 2010).

Velocity in this type of lagoon should allow particles to sink freely to the bottom and allow slow anaerobic decomposition (Suryani et al., 2017). Measurements of the speed of wastewater moving through the hydroponic ditch should be carried out regularly and preferably kept constant to ensure adequate flow conditions ensuring optimal time for the treatment processes. Measurements can be made using hydrometric grinders (based on electromagnets or mechanically acting), electromagnetic probes and even Dopplerbased devices such as ADCP (Turnipseed \& Sauer, 2010). The velocity measurements are especially important when the purified wastewater from the hydroponic lagoon is constantly flowing out to the receiving water body. This kind of measurements can be used, among others, to carry out the assumptions 
related to determining the volume of wastewater discharged to the receiver (Burgos et al., 2015).

The main objective of the research was to assess the conditions of sewage flow in the hydroponic lagoon by measuring the flow velocity and related selected quality parameters of treated sewage (BOD5, COD, TOC, turbidity, TSS) as well as the particle size distribution of suspended solids. The presented research is related to the wide scope of the performed analyses related to the measurement of the flow velocity in the semi-natural system which can lead to further improvement of the tertiary treatment in the hydroponic lagoon.

\section{Research Facility}

The research was carried out in a municipal wastewater treatment plant (WWTP) located in the Opolskie Voivodeship (N50.466487, E17.016908). The facility processes sewage supplied by a general sewerage network and transported by slurry tanks in the total amount around $1350 \mathrm{~m}^{3} \cdot \mathrm{d}^{-}$. The receiver of treated wastewater is the left-bank tributary of the Odra River-Nysa Kłodzka. There is a three-stage process of wastewater treatment in the treatment plant. First stage is the mechanical treatment with the use of screens and separator. Biological treatment takes place in the circulation hybrid biological reactor, using activated sludge flocks and settled biomass. The third stage of treatment is being realized in the so-called "artificial river" - the hydroponic lagoon. The length of the lagoon is $190 \mathrm{~m}$, the depth of the ditch is $1.4 \mathrm{~m}$ and its active capacity is $530 \mathrm{~m}^{3}$. The flow time through the lagoon is about $9 \mathrm{~h}$. The flow velocity according to the design assumptions should be around $0.006 \mathrm{~m} \cdot \mathrm{s}^{-1}$. The wastewater in hydroponic ditch is aerated with the use of bottom directional aerators which additionally support the flow of sewage. To support the wastewater treatment processes in the lagoon, the floating panels maintaining macrophytes over the entire surface of a single quarters were used. The plant species that grow on the lagoon plots are in particular Pistia stratiotes, Myriophyllum verticillatum and Limnobium laevigatum. Naturally occurring algae and Lemna minor are also observed. The hydroponic lagoon during the work of the aerators, being the main research facility is presented in the Fig. 1.

\section{Methodology}

The measurements including direct measurements in the lagoon (measurement of the sewage flow rate) were supported by laboratory analyses of physicochemical properties and granulometric composition of wastewater.

Measurements of the speed of sewage flowing through the hydroponic ditch were made at 12 measuring points. The scheme of the hydroponic lagoon with the measuring points is shown in the Fig. 2.

The direct speed measurement was made with an electromagnetic mill Valeport 801, whose principle of operation is based on Faraday's induction-the wastewater flowing around the head induces a current with a value proportional to the velocity of the flowing wastewater (Turnipseed \& Sauer, 2010). Due to low flow velocities and unchanging nature of the channel, i.e. constant width, depth and unchanging roughness (the bed is made entirely of precast concrete), it was decided to limit flow measurements to one hydrometric section in each profile. Measurements were made successively at depths of $0.1 \mathrm{~m}$, $0.3 \mathrm{~m}, 0.5 \mathrm{~m}$ and $1.0 \mathrm{~m}$. Figure 3 shows the crosssection of the hydroponic ditch with 4 depths of flow velocities measurements.

The content of organic matter in the sewage flowing through the lagoon was described by BOD5, COD and TOC. Also total suspended solids (TSS) concentration and turbidity were determined. The determination methods for the analysed indicators are presented in Table 1. From 9 of 12 measuring points, the sample of $1.5 \mathrm{~L}$ sewage from the depth of $0.1 \mathrm{~m}$ was taken. Wastewater samples were not collected in the immediate vicinity of aerators because of possibility of serious sewage quality disorders (cross-Sections. 6, 9, 11).

In selected measuring cross-sections, the size of the particles (granulometric composition) was measured with the use of Malvern Mastersizer 2000 laser granulometer. This device bases its operation on the Mie solution which allows you to determine the amount of light absorbed or dispersed by a spherical particle (Black et al., 1996). Mastersizer 2000 also uses the Fraunhofer model, which allows you to determine the size of the disc-shaped opaque particles (Chen et al., 2017) as it passes through the laser beam generated by the instrument. 
Fig. 1 Hydroponic lagoon in the municipal wastewater treatment plant: (a) WWTP building with hydroponic dich covered with polycarbonate sheets, (b) plant plot during the work of the bottom directional aerators, (c) Pistia stratiotes planted on the floating panels
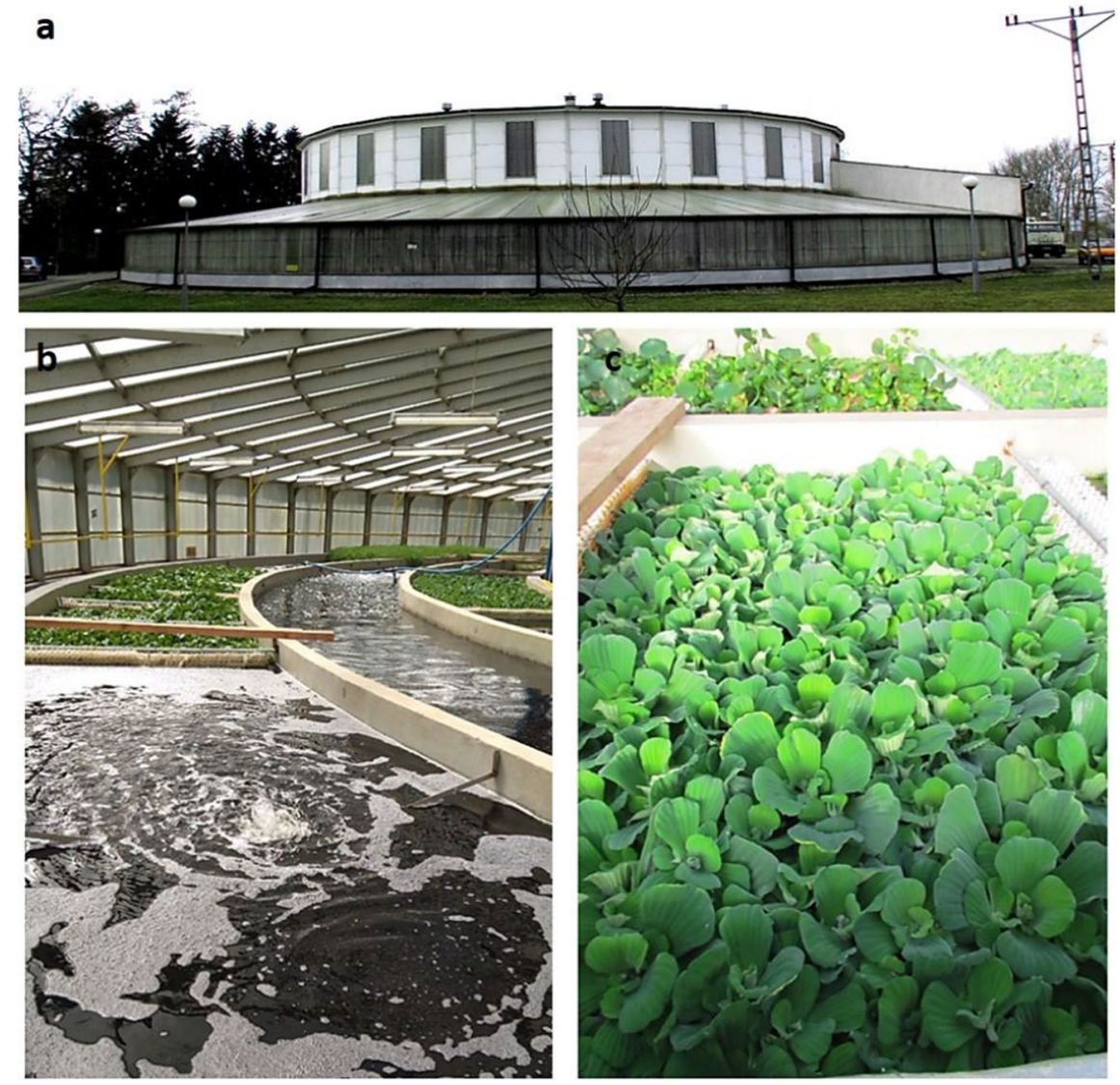

1 - points of velocity measurement

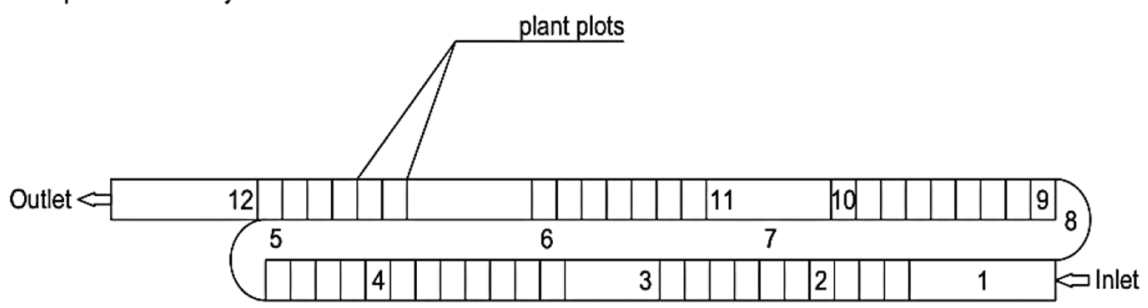

Fig. 2 Scheme of the hydroponic lagoon with 12 measuring points
Statistical analyses were performed using STATISTICA software.

\section{Results and Discussion}

The results of wastewater quality measurements indicated in the samples taken from the depth of $0.1 \mathrm{~m}$ in different cross-sections are presented in the Table 2.
The COD concentrations were successively decreasing during the flow through 5 measuring points. It can be noticed that during the flow through the middle part of the lagoon without macrophytes, the concentration increased. At the outflow to the receiver the COD value reached $50.00 \mathrm{gO}_{2} \cdot \mathrm{m}^{-3}$, and was slightly higher than the lowest identified value (44.90 $\mathrm{gO}_{2} \cdot \mathrm{m}^{-3}$ ). The COD concentration in the 10th cross-section is higher than in the first one because of the wastewater flow through the plant plots. The 
Fig. 3 The scheme of the measurement cross-section of the hydroponic ditch (v) velocity measurement

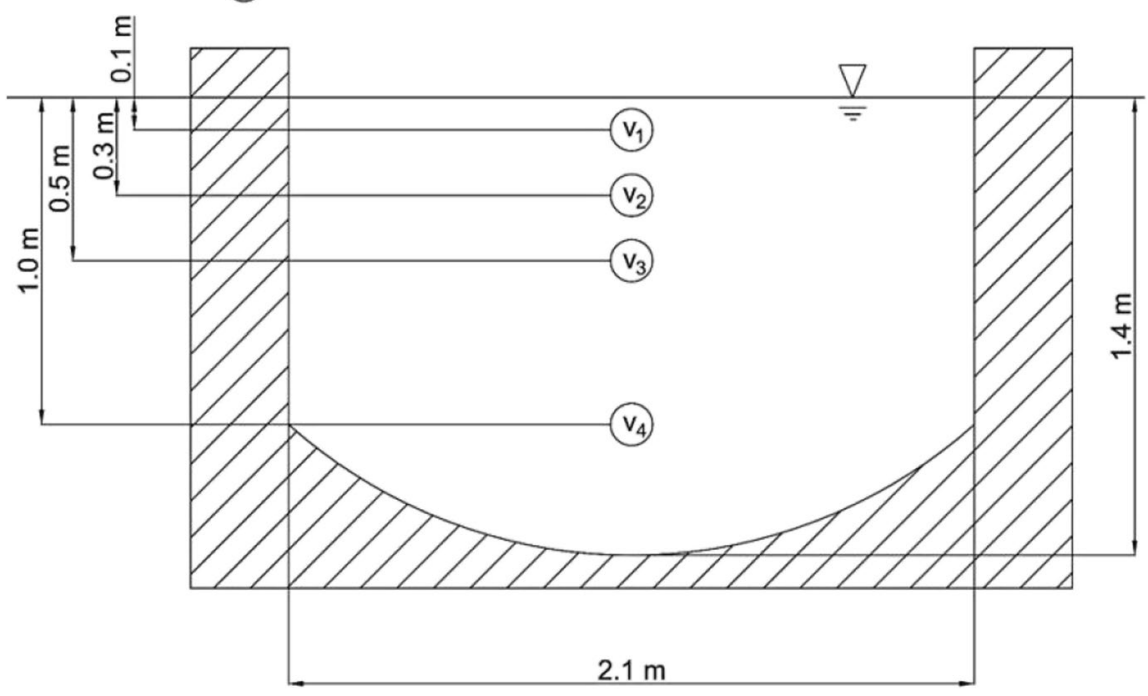

Table 1 Determination methods and laboratory testing standards for sewage quality indicators
Table 2 Wastewater quality in the selected measuring cross-sections

\begin{tabular}{lll}
\hline Parameter & Determination method & Laboratory testing standard \\
\hline COD $\left[\mathrm{gO}_{2} \cdot \mathrm{m}^{-3}\right]$ & Dichromate method & PN-ISO6060:2006 \\
BOD5 $\left[\mathrm{gO}_{2} \cdot \mathrm{m}^{-3}\right]$ & Electrochemical method & PN-EN ISO5815-1:2019-12 \\
TOC $[\mathrm{ppm}]$ & Oxidation in supercritical conditions & - \\
Turbidity $[\mathrm{NTU}]$ & Nephelometric method & PN-EN ISO 7027 \\
TSS $\left[\mathrm{g} \cdot \mathrm{m}^{-3}\right]$ & Weight method with filtration & PN-EN 872:2005 \\
\hline
\end{tabular}

\begin{tabular}{|c|c|c|c|c|c|c|c|c|c|c|c|c|}
\hline \multirow[t]{2}{*}{ Parameter } & \multicolumn{12}{|c|}{ Cross-section } \\
\hline & 1 & 2 & 3 & 4 & 5 & 6 & 7 & 8 & 9 & 10 & 11 & 12 \\
\hline $\mathrm{COD}\left[\mathrm{gO}_{2} \cdot \mathrm{m}^{-3}\right]$ & 75.90 & 54.50 & 53.10 & 53.10 & 44.90 & - & 49.00 & 50.40 & & 82.80 & - & 50.00 \\
\hline $\mathrm{BOD} 5\left[\mathrm{gO}_{2} \cdot \mathrm{m}^{-3}\right]$ & 10.60 & 9.60 & 3.70 & 7.10 & 5.70 & - & 2.90 & 1.50 & 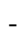 & 1.20 & - & 1.20 \\
\hline TOC[ppm] & 17.90 & 12.90 & 9.43 & 9.66 & 12.10 & - & 8.74 & 8.03 & - & 6.19 & - & 6.50 \\
\hline Turbidity[NTU] & 12.87 & 9.83 & 3.89 & 2.96 & 1.43 & - & 3.04 & 1.59 & - & 0.96 & - & 0.28 \\
\hline $\mathrm{TSS}\left[\mathrm{g} \cdot \mathrm{m}^{-3}\right]$ & 125.00 & 35.00 & 10.00 & 40.00 & 20.00 & - & 10.00 & 25.00 & - & 20.00 & - & 25.00 \\
\hline
\end{tabular}

growth of macrophytes and minor fauna associated with the plants it involves the death of organisms and the enrichment of wastewater with organic matter. Because of this phenomenon, the last section of hydroponic lagoon before the sewage outflow is devoid of plants and bottom aerators and aerators which work could cause resuspension of bottom sediments. The COD removal efficiency reached $34.1 \%$. The highest BOD5 concentration was identified in the first measuring point, where wastewater clarified in the secondary settling tank flows into the hydroponic ditch. The concentration was varying during the flow but at the outflow of the ditch, it decreased reaching the value of $1.20 \mathrm{gO}_{2} \cdot \mathrm{m}^{-3}$. Comparing the inlet to the lagoon and the outlet, the efficiency of BOD5 removal was $88.7 \%$. Similar tendency can be observed for TOC concentration - it varied during the flow through the hydroponic lagoon, but at the outflow, the lowest concentration was identified and the removal efficiency reached $63.7 \%$. The total suspended solids concentration reached the average value of $34.40 \mathrm{~g} \cdot \mathrm{m}^{-3}$. At the outflow, the concentration was 
5 times lower than at the inflow to the lagoon what provided $80 \%$ removal efficiency. Due to decrease of TSS concentration in wastewater also the turbidity has decreased (by 97.8\%).

The measured flow velocity had a similar course for all analysed depths. Changes in the speed of sewage flow in the hydroponic lagoon at different depths are presented in Fig. 4.

The average value of flow velocity was at a similar level for all depths and reached $0.070-0.073 \mathrm{~m} \cdot \mathrm{s}^{-1}$ with the maximum value measured at a depth of $0.1 \mathrm{~m}$ at measuring point 1 (inlet to the lagoon). At the outlet of the lagoon, higher sewage flow rates were observed for deeper levels $(0.5-1.0 \mathrm{~m})$. This phenomenon may affect the elevation of previously deposited on the bottom of the lagoon particles. In addition, the increase in speed at points 9 and 11 in surface wastewater layers is caused by the work of aerators. Plants planted on the plastic panels placed on the sewage surface can be used to control flow conditions and prevent outflow of floating particles to the receiver (Kadlec, 2008).

Because of the design of the outlet - sewage outflow through an overflow at the level of the sewage table, the measurements of wastewater quality were made for samples taken from the depth of $0.1 \mathrm{~m}$. Therefore, the flow velocity at the depth of $0.1 \mathrm{~m}$ has the biggest impact on pollutants concentration.

The analysis of correlation between organic matter and total suspended solids concentration and the flow velocity have shown that dependencies between those factors occurred. In each of the reported cases, the correlation was positive but it showed small values of the correlation coefficient. The calculated Pearson's correlation coefficient ( $r$ ) reached the highest value for TSS and TOC and is sequentially 0.66 and 0.65 . The value of correlation coefficient higher than 0.6 shows a significant dependence of the concentration of these components on the wastewater flow velocity. The Pearson's $r$ value close to 0.4 obtained for the COD (0.42) and BOD5 (0.36) indicates that the correlation between those parameters and flow velocity is low (Schroeder et al., 2016). The results of analyses are presented in Fig. 5a-d.

The particle size distribution of suspended solids in a hydroponic lagoon with a $\%$ content of particles is presented in Fig. 6 . The range of the particles sizes found in the sewage is usually diversified and can be treated as individual for each area, from which the sewage is discharged through the collective sewage system to the treatment plant (Burszta-Adamiak et al., 2012).

Analyses of granulometric composition of particles showed that at designed measurement points, the particle diameters varied in the range of $0.8-800 \mu \mathrm{m}$. The particles with the largest equivalent diameters were identified in the first measurement point (inlet to the lagoon) - over $90 \%$ of the particles for this measurement were characterized by a diameter of more than $178.5 \mu \mathrm{m}$. This sampling point is usually characterized by the highest variations of the particle diameters because the
Fig. 4 Changes in the speed of sewage flow in the hydroponic lagoon at different depths

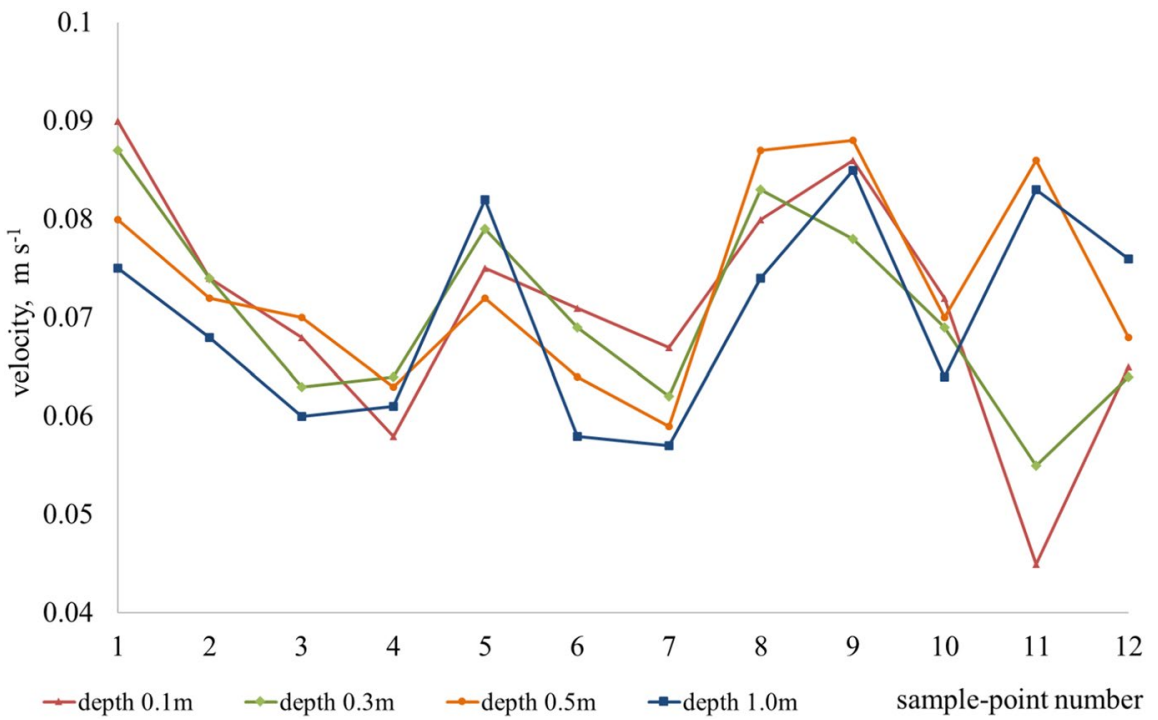



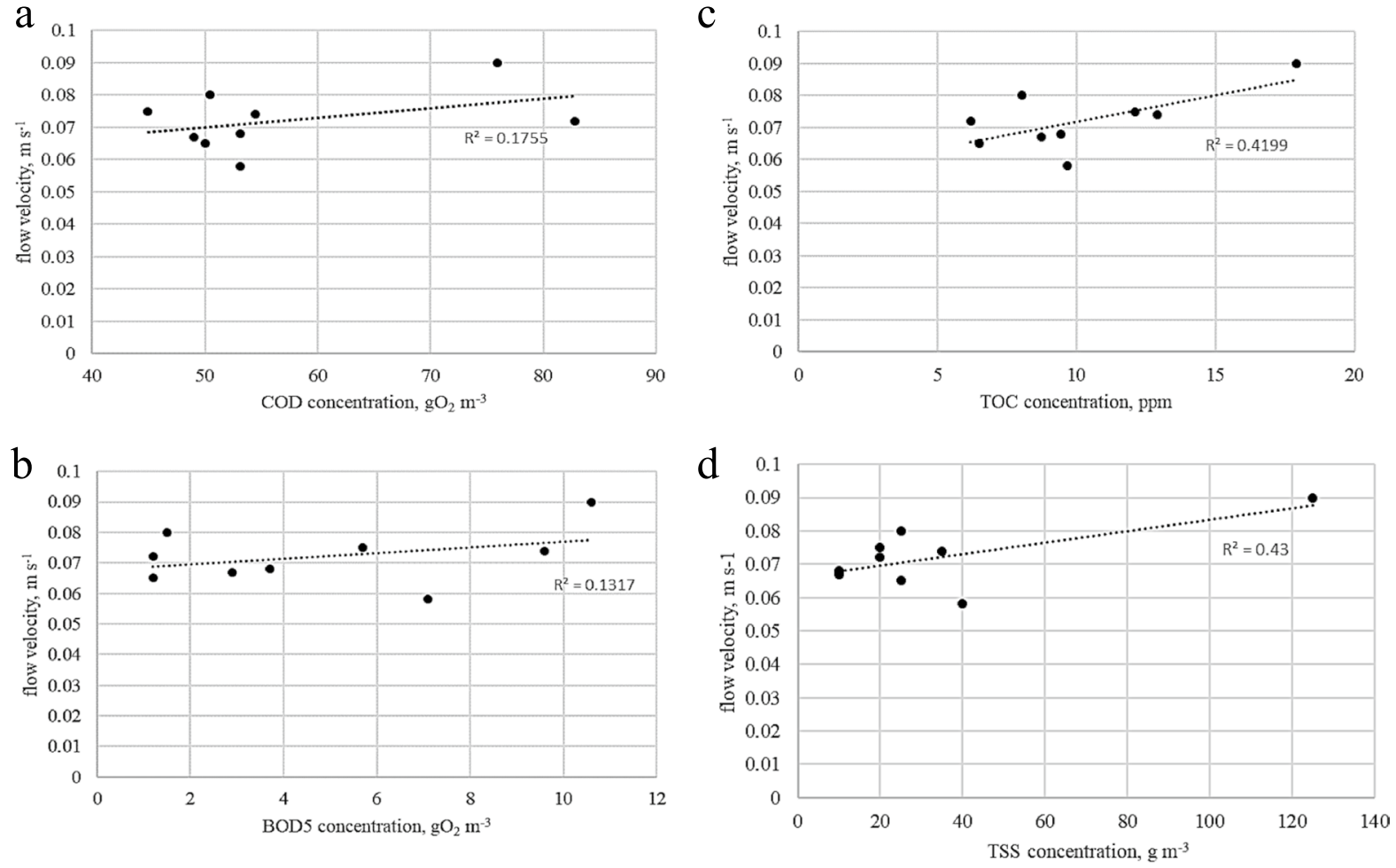

Fig. 5 Correlation between wastewater pollution indicators $(\mathbf{a}-$ COD, $\mathbf{b}-$ BOD5, $\mathbf{c}-$ TOC, $\mathbf{d}-$ TSS $)$ and flow velocity of the sewage

Fig. 6 The particle size distribution of suspended solids in a hydroponic lagoon with a $\%$ content of particles

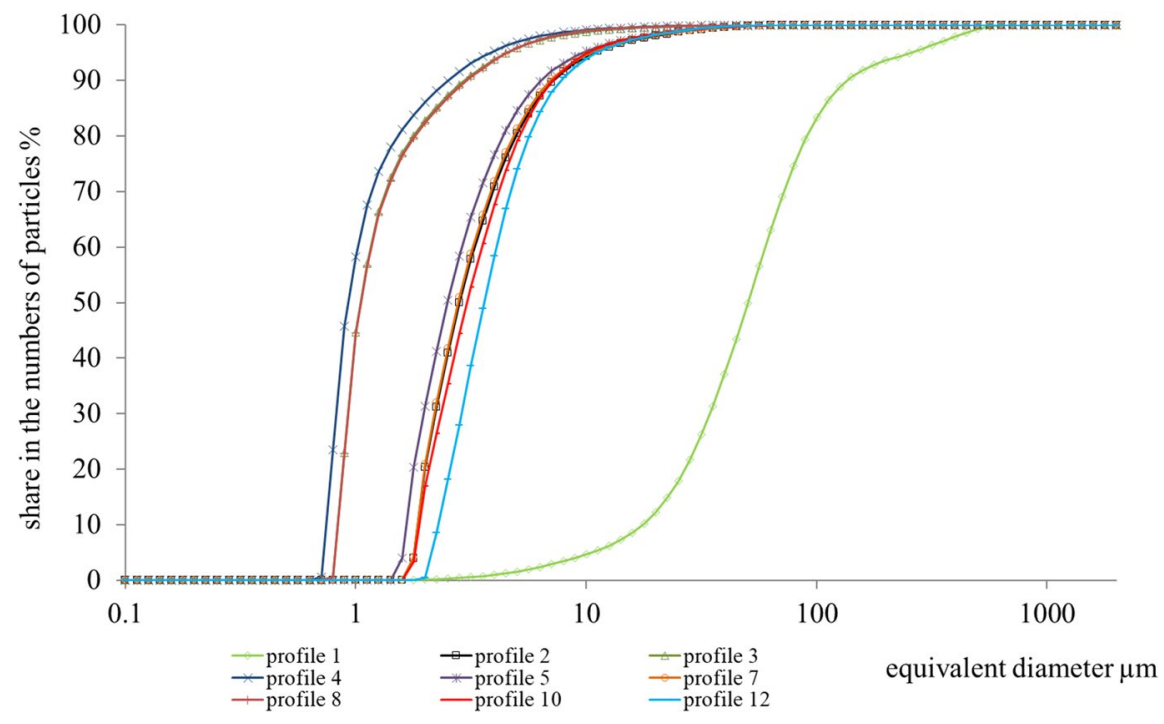

wastewater is flowing straight from the secondary settling tank (Bawiec \& Pawęska, 2020). In the remaining cross-sections, $90 \%$ of the particles were within the limits of $0.8-8.7 \mu \mathrm{m}$. As the flow of sewage through the hydroponic lagoon progressed, the particle size decreased (disaggregation), which was probably caused by the increase of the flow velocity of sewage forced by an air introduced into 
the lagoon by the aeration system. Periodic aeration may cause occurrence of the advection process and deterioration of sedimentation conditions leading to uncontrolled outflow of small suspensions from the hydroponic ditch (Fries et al., 2008; Walters et al., 2014).

\section{Conclusions}

On the basis of observations and performed tests and analyses, the following conclusions were formulated:

- Average measured velocity in the system of aerated hydroponic lagoon was $0.070 \mathrm{~m} \cdot \mathrm{s}^{-1}$, which was ten times higher than the assumed rate of sewage displacement in the lagoon. Increase of the velocity changes the sedimentation condition in hydroponic ditch.

- Speed values caused by frequent and rapid work of aerators cause dynamic movement of organic matter and prevent slow sedimentation of particles to the bottom of the lagoon. This leads to outflow of organic matter to the receiving water body.

- The correlation between organic matter expressed by TOC and total suspended solids concentrations and the flow velocity of the sewage in hydroponic lagoon occurred. The correlation between BOD5 and COD and the flow velocity is slight. Further research is required to conclude whether the velocity of the sewage increases the concentration of pollutants in the surface layer of wastewater flowing through the ditch.

- The largest particle diameters were observed at the inlet to the lagoon where wastewater from the secondary settling tank is discharged. Over $90 \%$ of the particles had diameters greater than $178.5 \mu \mathrm{m}$. The particle diameters along with the sewage flow were reduced in the range from 800 to $0.8 \mu \mathrm{m}$.

- The values of parameters describing the content of organic matter in sewage were within the standards describing the quality of treated wastewater; however, improving the hydraulic conditions in hydroponic ditch may lead to higher sewage treatment efficiency and hence to better protection of natural ecosystems.
Author Contribution Katarzyna Pawęska wrote the main manuscript text and along with Aleksandra Bawiec prepared all the samples, measurements and analyzes with the help of Kinga Marek and Jeremi Baran. Katarzyna Pawęska and Aleksandra Bawiec conceived the ideas and developed the methodological and analytical framework and interpreted the results. All authors reviewed the manuscript.

Data Availability The authors confirm that the data supporting the findings of this study are available within the article.

Code Availability Not applicable

\section{Declarations}

Conflict of Interest The authors declare no competing interests.

Open Access This article is licensed under a Creative Commons Attribution 4.0 International License, which permits use, sharing, adaptation, distribution and reproduction in any medium or format, as long as you give appropriate credit to the original author(s) and the source, provide a link to the Creative Commons licence, and indicate if changes were made. The images or other third party material in this article are included in the article's Creative Commons licence, unless indicated otherwise in a credit line to the material. If material is not included in the article's Creative Commons licence and your intended use is not permitted by statutory regulation or exceeds the permitted use, you will need to obtain permission directly from the copyright holder. To view a copy of this licence, visit http://creativecommons.org/licenses/by/4.0/.

\section{References}

Jin, Z., Zhang, X., Li, J., Yang, F., Kong, D., Wei, R., Huang, K., \& Zhou, B. (2017). Impact of wastewater treatment plant effluent on an urban river. Journal of Freshwater Ecology, 32(1), 697-710. https://doi.org/10.1080/02705 060.2017.1394917

Atique, U., \& An, K. G. (2020). Landscape heterogeneity impacts water chemistry, nutrient regime, organic matter and chlorophyll dynamics in agricultural reservoirs. Ecological Indicators, 110, 105813. https://doi.org/10.1016/j. ecolind.2019.105813

Szabo, H. M., \& Lepistö, R. (2020). HPLC-SEC chromatograms as surrogates for BOD and other organic quality indicators of septic tank effluents. International Journal of Environmental Science and Technology., 17, 483-492. https://doi.org/10.1007/s13762-019-02518-w

Zhu, L., Li, X., Zhang, C., \& C. \& Duan, Z. . (2017). Pollutants' release, redistribution and remediation of black smelly river sediment based on re-suspension and deep aeration of sediment. International Journal of Environmental Research and Public Health., 4, 374. https://doi. org/10.3390/ijerph14040374 
Panda, U. S., Mahanty, M. M., Rao, V. R., Patra, S., \& Mishra, P. (2015). Hydrodynamics and water quality in Chilika Lagoon-A modelling approach. Procedia Engineering., 116(1), 639-646. https://doi.org/10.1016/j.proeng.2015. 08.337

Maiga, Y., Sperling, M. \& Mihelcic, J.R. (2017). “Consructed Wetlands" in book: Global Water Pathogen Project, Ed. C. Haas, J. Mihelcic, M. Verbyla, Michigan State University, E. Lansing, MI, UNESCO

Keeratiurai, P. (2013). Efficiency of wastewater treatment with hydroponics. ARPN Journal of Agricultural and Biological Science, 8(12), 800-805.

Taseiko, O., Spitsina, T., Milosevic, H., Radovanovic, D. \& A. Valjarevic, A. (2016). Biochemical processes of self-purification model in small rivers. Mathematical and Information Technologies MIT-2016-Methematical modelling. Retrieved February 19, 2021, from http://ceur-ws.org/Vol1839/MIT2016-p41.pdf

Ghosh, S. N., \& Desai, V. R. (2016). Environmental hydrology and hydraulics eco-technological practices for sustainable development. CRC PRESS, Boca Raton. https://doi.org/ 10.1201/b11004

Wu, B. (2010). CFD Analysis of mixing in large aerated lagoons. Engineering Applications of Computational Fluid Mechanics, 4(1), 127-138. https://doi.org/10.1080/ 19942060.2010.11015304

Bawiec, A., Pawęska, K., \& Pulikowski, K. (2020). LED light use for the improvement of wastewater treatment in the hydroponic system. Environmental Technology, 41(16), 2024-2036. https://doi.org/10.1080/09593330.2018. 1554007

Suryani, S., \& Maharani \& Hamzah, M.A. . (2017). Proposing of an aerated water treatment plant for reducing water pollution problem in Losari Beach after reclamation. AIP Conference Proceedings, 1801, 060006-1-060006-4. https://doi.org/10.1063/1.4973110

Huang, B., Hong, C., Du, H., Qiu, J., Liang, X., Tan, C., \& Liu, D. (2017). Quantitative study of degradation coefficient of pollutant against the flow velocity. Journal of Hydrodynamics, 29(1), 118-123. https://doi.org/10.1016/S10016058(16)60723-0

Brodersen, K. E., Hammer, K. J., Schrameyer, V., Floytrup, A., Rasheed, M. A., Ralph, P. J., Kühl, M., \& Pedersen, O. (2017). Sediment resuspension and deposition on seagrass leaves impedes internal plant aeration and promotes phytotoxic $\mathrm{H}_{2} \mathrm{~S}$ intrusion. Frontiers in Plant Science, 8, 657. https://doi.org/10.3389/fpls.2017.00657

Wang, C., Zheng, S., Wang, P., \& Hou, J. (2015). Interactions between vegetation, water flow and sediment transport: A review. Journal of Hydrodynamics, 27(1), 24-37. https:// doi.org/10.1016/S1001-6058(15)60453-X

Burgos, A.J., López, J.S. \& Rodriguez, P.U. (2015). Technology fact sheets for effluent treatment plants on textile industry aerated ponds. Series: secondary treatments FSBIO-011. Retrieved February 19, 2021, from https://www. wateractionplan.com/documents/177327/558166/Aerat ed+ponds.pdf/8fefcd82-8da1-f6e0-2d58-b6a0365e7edc

Turnipseed, D. P., \& Sauer, V. B. (2010). Discharge measurements at gaging stations U.S. Geological Survey Techniques and Methods book, 3(A8), 87. https://doi.org/10. 3133/tm3A8

Black, D. L., McQuay, M. Q., \& Bonin, M. P. (1996). Laserbased techniques for particle-size measurement: A review of sizing methods and their industrial applications. Progress in Energy and Combustion Science, 22(3), 267-306. https://doi.org/10.1016/S0360-1285(96)00008-1

Chen, Q., Liu, W., Wang, W., Thomas, J. C., \& Shen, J. (2017). Particle sizing by the Fraunhofer diffraction method based on an approximate non-negatively constrained Chin-Shifrin algorithm. Powder Technology, 317, 95-103. https:// doi.org/10.1016/j.powtec.2017.04.047

Kadlec, R. H. (2008). The effects of wetland vegetation and morphology on nitrogen processing. Ecological Engineering, 33(2), 126-14. https://doi.org/10.1016/j.ecoleng. 2008.02.012

Schroeder, L. D., Sjoquist, D. L., \& Stephan, P. E. (2016). Understanding regression analysis: An introductory guide. SAGE Publication.

Burszta-Adamiak, E., Kuśnierz, M., Łomotowski, J. \& Wiercik, P. (2012). The research on grain size distribution in suspension occurring in municipal and industrial wastewater. Infrastructure and Ecology of Rural Areas, 3/ III, 43-54. (in Polish)

Bawiec, A., \& Pawęska, K. (2020). Changes in the granulometric composition of particles in wastewater flowing through a hydroponic lagoon used as the third stage in a wastewater treatment plant. Water Science and Technology, 81(9), 1863-1869. https://doi.org/10.2166/wst.2020.235

Fries, J. S., Characklis, G. W., \& Noble, R. T. (2008). Sediment water exchange of Vibrio sp. and fecal indicator bacteria: Implications for persistence and transport in the Neuse River Estuary, North Carolina, USA. Water Research, 42, 941-950. https://doi.org/10.1016/j.watres.2007.09.006

Walters, E., Graml, M., Behle, C. E., \& Muller, H. (2014). Horn influence of particle association and suspended solids on UV inactivation of fecal indicator bacteria in an urban river. Water Air \& Soil Pollution, 225, 1822. https:// doi.org/10.1007/s11270-013-1822-8

Publisher's Note Springer Nature remains neutral with regard to jurisdictional claims in published maps and institutional affiliations. 